\title{
Assessment of Seasonal Drought Impact on Potato in the Northern Single Cropping Area of China
}

\author{
Dao Riao ${ }^{1,2,3,4}$, Xingpeng Liu ${ }^{1}$, Suri Guga ${ }^{1,2,3,4}$, Jie Xu ${ }^{1,2,3,4}$, Kaiwei Li 1,2,3,4, Mingxi Zhang ${ }^{1,2,3,4}$ \\ and Jiquan Zhang 1,2,3,4,* \\ 1 School of Environment, Northeast Normal University, Changchun 130024, China; \\ daora388@nenu.edu.cn (D.R.); liuxp912@nenu.edu.cn (X.L.); surgg146@nenu.edu.cn (S.G.); \\ xuj463@nenu.edu.cn (J.X.); likw395@nenu.edu.cn (K.L.); zhangyq017@nenu.edu.cn (M.Z.) \\ 2 Key Laboratory for Vegetation Ecology, Ministry of Education, Changchun 130024, China \\ 3 State Environmental Protection Key Laboratory of Wetland Ecology and Vegetation Restoration, \\ Changchun 130024, China \\ 4 Jilin Province Science and Technology Innovation Center of Agro-Meteorological Disaster Risk Assessment \\ and Prevention, Northeast Normal University, Changchun 130024, China \\ * Correspondence: zhangjq022@nenu.edu.cn; Tel.: +86-135-9608-6467
}

check for updates

Citation: Riao, D.; Liu, X.; Guga, S.; Xu, J.; Li, K.; Zhang, M.; Zhang, J. Assessment of Seasonal Drought Impact on Potato in the Northern Single Cropping Area of China. Water 2022, 14, 494. https://doi.org/ $10.3390 /$ w14030494

Academic Editors: Qiang Fu, Yongqiang Cao, Tianxiao Li and Mo Li

Received: 23 December 2021

Accepted: 4 February 2022

Published: 7 February 2022

Publisher's Note: MDPI stays neutral with regard to jurisdictional claims in published maps and institutional affiliations.

Copyright: (C) 2022 by the authors. Licensee MDPI, Basel, Switzerland. This article is an open access article distributed under the terms and conditions of the Creative Commons Attribution (CC BY) license (https:// creativecommons.org/licenses/by/ $4.0 /)$.

\begin{abstract}
Drought is one of the key limiting factors for potato yield in the northern single cropping area (NSCA) in China. To analyze the impact of drought on potato yield in the NSCA, this study first analyzed the variation of dry/wet conditions in the plantable areas on a seasonal scale using the standardized precipitation evapotranspiration index (SPEI). Secondly, the changes in yield structure in the last 36 years were systematically analyzed and divided the total yield change into planting area contribution and climate yield contribution. Finally, a regression model of the seasonal drought index and contributing factors of total yield change in different administrative regions was constructed. The results showed that the main factors affecting the total potato yield of the NSCA began to change from yield to planting area in the 1990s, while the barycenter of the output structure and population moved to the southwest, with grassland being the main source; dry/wet conditions (year i) had varying degrees of effect on contributing factors (year i, year $i+1$ ) of total yield change in different administrative regions that were not limited to the growing season; the non-overlap of high-yield area, high-adaptability area and planting area was the urgent problem to be solved for the NSCA. The results of this study can provide a scientific basis for NSCA crop management and communication with farmers, providing new ideas for sustainable production in other agricultural regions in the world.
\end{abstract}

Keywords: drought; potato; contribution factor; model; season; China

\section{Introduction}

Food production and climate change maintain a close causality, especially in the current ecological environment, where a certain degree of damage, extreme weather conditions and climate variability have become key factors directly affecting food security. Climate change brings extreme weather and precipitation heterogeneity that seriously threaten food security in agroecosystems [1]. The Food and Agriculture Organization of the United Nations (FAO) research report highlights that agricultural production will be seriously impacted by climate change in the next 2 to 5 decades, seriously affecting global food security in the long term [2]. Among them, the agricultural drought seriously hinders agricultural development in developing countries and is a complex worldwide phenomenon. The World Bank released a report saying that enough food has been destroyed by the drought to feed more than 80 million people for up to a year.

Potato (scientific name: Solanum tuberosum L.) is an annual herb from South America (Peru) with edible tubers. It was introduced to other continents as an important food 
crop. As the most important food crop after rice, wheat and maize, the potato is classified as a strategic food reserve by many countries because of its nutritional richness [3-6]. According to the FAO, $68 \%$ of the world's countries and territories planted potato in 2018 [2]. The United Nations designated 2008 as the International Year of the Potato, calling the potato a "buried treasure" and calling on the world to pay attention to the irreplaceable importance of the potato in alleviating the food crisis, ensuring food security and achieving the Millennium Development Goals. Potato grows best in both warm and cool climates, but it does not tolerate drought, heat or relative air humidity [7]. Thus, in the context of climate change, the relationship between potato yield and drought has attracted the attention of scholars worldwide. When the mean temperature and moisture content exceeds the acceptable level for potato, the normal growth of the rootstock and vine will be affected, leading to a decrease in yield [8-13]. In projecting future potato yields in the context of climate change on a global scale, it is noted that climate change increases seasonal variability, but uncertainty is also significant. It also makes pessimistic forecasts for yields in the main production areas of China.

Agriculture is easily affected by drought in China. From 1984 to 2018, the area of crops affected by drought reached $2.0 \times 10^{5} \mathrm{~km}^{2}$ every year [14]. As a populous country, more than $98 \%$ of China's agricultural operators are still small-scale farmers, lacking in awareness of scientific potato planting, especially in northern China [15]. When the contradiction between population and cultivated land resources is prominent, farmers' lack of awareness of agrometeorological disasters will bring huge losses to agriculture $[16,17]$. Several instances of research also proved that the potential contribution of potato to China's food self-sufficiency is far greater than that of the three other main food crops (rice, corn, wheat) [18].

China has been the world's largest potato producer since 1993 [19]. There are four main potato-growing areas in China, with different maturity systems and agro-climatic resources. Until now, the north single cropping area (NSCA) has been the main producing area and an important seed potato base because of its climatic advantage as well as the advantage of cultivated land resources $[20,21]$. However, drought disasters have become one of the main natural disasters in the NSCA, affecting the normal development of agriculture and animal husbandry. The planting areas of potato are mainly concentrated in rain-fed agricultural areas with poor irrigation conditions. With the passage of time, precipitation has had a greater and greater impact on the key growth period of potato $[7,19,22]$. Studies also have shown that potato yields depend on conditions such as temperature and precipitation not only during the growing season but also before planting [13]. Farmers will base their planting arrangements for the next year on historical experience-for example, film mulching in different seasons, double ridge side-sowing, straw crop rotation, selection of different varieties, irrigation, land preparation, construction of sheds [23-25]. The above influences are summarized as factors that determine the contribution of crop yield: (1) planted area and (2) yield [26].

Nowadays, Chinese agricultural production has entered a new stage. However, preexisting pressures affecting food security persist: (1) climate change and (2) reduction in the quantity and quality of cultivated land [23]. Hence, this study is designed to, using longterm data sets: (1) understand the characteristics of the variation of dry/wet conditions in the NSCA, the China main potato producing area, over four seasons, (2) analyze the variation characteristics of the potato total yield in the NSCA and (3) establish a model of the relationship between the seasonal drought index and contributing factors of total yield change in the NSCA's different administrative regions. We expect that our study can provide a basis for agricultural policy adjustments and communication with smallholder farmers as well as provide a new idea for sustainable potato production. 


\section{Materials and Methods}

\subsection{Study Area}

The NSCA, which is located at longitude $73-136^{\circ} \mathrm{E}$ and latitude $31-54^{\circ} \mathrm{N}$ (Figure 1 ), is the major potato-producing area and seed potato base in China, with $43 \%$ of the planted area and $42 \%$ of the total production in 2017. It is also the main production place of fresh vegetable varieties and starch-processing varieties in China. Based on geographical location and climatic conditions, potato cultivation in China is divided into four regions with different agro-climatic resources and maturity systems: (1) the north single cropping area (NSCA) in the north, (2) the double season area in the central plains, (3) the single and double mixed area in the southwest and (4) the winter cropping area in the south. The potato cultivation system in the NSCA is single crop per year, sowing in spring and harvesting in autumn, with mainly dry farming. The NSCA, from east to west, includes Heilongjiang, Jilin, Inner Mongolia, Hebei, Shanxi, Shaanxi, Gansu, Ningxia, Qinghai and Xinjiang. The main planting varieties are Kexin 1, FAVORITA, Youjin, Atlantic and Qingshu 9.

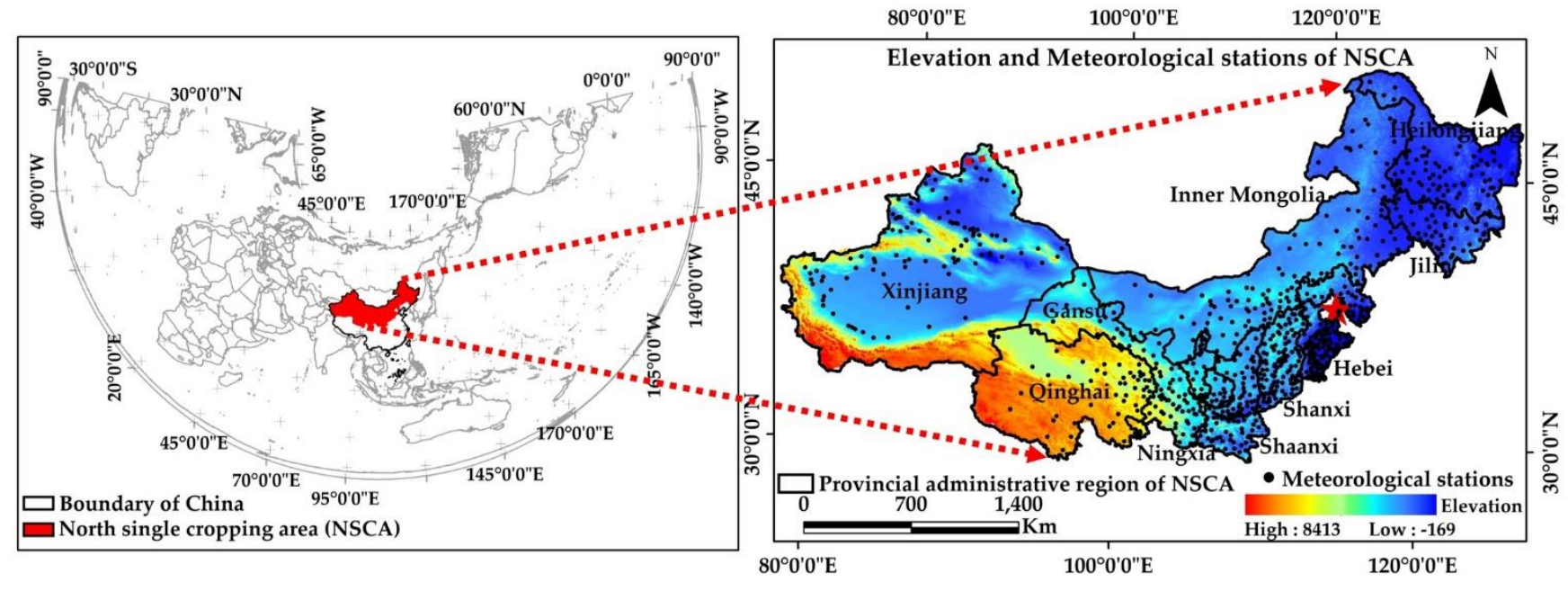

Figure 1. Location and basic characteristics of NSCA.

\subsection{Data Collection}

The data of potato were obtained from China Agricultural Yearbook, consisting of the total yields (10,000 t), planting area (1000 ha) and yield ( $\mathrm{kg} / \mathrm{ha})$ data of 36 years (1982 to 2017). The population data were obtained from China Statistical Yearbook. The climate data were obtained from China Meteorological Sharing Service System (http://data.cma.cn, accessed on 24 April 2021), including daily meteorological data of 900 meteorological stations from 1960 to 2019 (Figure 1). Meteorological stations include national benchmark stations, basic stations and general stations. Land use type data are the spatial distribution data of land use type remote sensing monitoring from the Resource and Environmental Science and Data Center (https: / / www.resdc.cn, accessed on 28 March 2021). It is generated through manual visual interpretation based on Landsat TM images of the U.S. Landsat. Land use types include cultivated land, woodland, grassland, waters, construction land and unused land.

\subsection{Methods}

\subsubsection{Standardized Precipitation Evapotranspiration Index}

In order to monitor and study the drought process under the background of global warming, Vicente et al. [27] proposed the standardized precipitation evapotranspiration index (SPEI). The SPEI index not only considers the temperature sensitivity of evapotranspiration but also has the advantages of multi-scale and multi-spatial comparison. It is an ideal index for drought monitoring and evaluation under the background of climate 
warming, and it is widely used in drought research. In the study, we used the SPEI index to calculate the dry/wet conditions of the NSCA in different seasons.

\subsubsection{Decomposition of Contribution Factors of Total Yield}

From the composition of crop yield, the increase or decrease of total yield is determined by change in planting area and yield. Therefore, the change in crop yield can be divided into planting area contribution and yield contribution [23].

$$
\begin{gathered}
\mathrm{Cr}=\frac{\Delta \mathrm{Gy}}{\Delta \mathrm{G}} \\
\mathrm{Cs}=\frac{\Delta \mathrm{Gs}}{\Delta \mathrm{G}} \\
\Delta \mathrm{Gy}=\Delta \mathrm{G}-\Delta \mathrm{Gs} \\
\Delta \mathrm{Gs}=\mathrm{Yt} \times \Delta \mathrm{Sn}
\end{gathered}
$$

where $\mathrm{Cr}$ is the contribution rate of crop yield and $\mathrm{Cs}$ is the contribution rate of planting area. $\Delta \mathrm{G}$ is the change in crop yield, $\Delta \mathrm{Gy}$ is the yield contributed by the change in crop yield and $\Delta \mathrm{Gs}$ is the yield contributed by the change in crop planting area. Yt is the weighted average yield of the crop in the target year, $\Delta S n$ is the change in crop planting area.

a. $\mathrm{Y}_{\mathrm{r}}$-fluctuation rate of yield.

$$
\mathrm{Y}_{\mathrm{r}}=\frac{\mathrm{Y}-\mathrm{Y}_{\mathrm{t}}}{\mathrm{Y}}=\frac{\mathrm{Y}_{\mathrm{c}}}{\mathrm{Y}}
$$

where $Y_{r}$ is fluctuation rate of yield, $Y$ is actual crop yield, $Y_{t}$ is trend yield and $Y_{c}$ is climate-induced yield.

b. $\mathrm{S}_{\mathrm{r}}$-fluctuation rate of planting area.

$$
\mathrm{s}_{\mathrm{r}}=\frac{\mathrm{S}_{\mathrm{i}}-\mathrm{s}_{\mathrm{i}-1}}{\mathrm{~S}_{\mathrm{i}-1}}
$$

where $S_{r}$ is fluctuation rate of planting area, $S_{i}$ is planting area in year $i$ and $S_{i-1}$ is planting area in year $\mathrm{i}-1$.

\subsubsection{Climate-Induced Yield}

The variations of crop yield are not only related to climatic factors but are also closely related to scientific and technological progress (production method and variety), material input (field management), environmental changes, policy and many other factors [28,29]. Therefore, crop yield is generally divided into three parts: trend yield, climate-induced yield and random error. Trend yield reflects the productivity level of a certain crop in a certain region in a certain historical period. Climate change is the main factor affecting yield fluctuations. Random error, also known as "random noise", is generally ignored in studies. Extracting climate-induced yield from crop yield is the most common method to study the relationship between climatic factors and crop yield.

Hodrick and Prescott [30] proposed the Hodrick-Prescott filter (HP filter) model to study the economic problems of the United States after the Second World War [31-34]. The basic assumption of the model is that the time series data can be regarded as a combination of the trend and periodic components. This model can effectively separate two parts of the data. We regard the HP filter as a high-pass filter, which separates the actual crop yield into high-frequency (climate-induced yield) and low-frequency components (trend yield) $[29,35]$. Compared with the moving average method, the separated climate-induced yield is synchronized with the original actual yield year, and there are no missing data in the first and last years of the data series. It is suitable for analysis of small sample sizes and limited information. The correlation between the trend yield and the corresponding actual yield of different administrative units obtained by HP filtering method was more 
than $50 \%$, and the regression relationship passed the 0.01 significance test (Table A1). Thus, the results show that the method can accurately reflect the trend yield of NSCA potato and could calculate the climate-induced yield of NSCA potato.

\subsubsection{Shift of Barycenter}

In this study, the spatial change process of yield structure of potato crops and population barycenter in the NSCA over the years was studied using the principle of population barycenter in population geography. The whole NSCA was selected as the study area, and 10 provincial administrative regions were selected as secondary areas. Specifically, the longitude and latitude of the center of 10 provincial administrative regions were taken as the calculation parameters, and the relevant attribute data set of each administrative region was considered the calculation attribute value. In addition, dimensionless processing was performed to ensure the comparability of the data [36,37].

$$
\begin{aligned}
& X_{t}=\sum_{i=1}^{n}\left(s_{t i} \times X_{i}\right) / \sum_{i=1}^{n} s_{t i} \\
& Y_{t}=\sum_{i=1}^{n}\left(s_{t i} \times Y_{i}\right) / \sum_{i=1}^{n} s_{t i}
\end{aligned}
$$

where $X_{t}$ and $Y_{t}$ represent the longitude and latitude coordinates of the barycenter of a certain attribute in the study area in the $t$-th year, respectively; $S_{t i}$ represents the magnitude of class $i$ attribute in the $t$-th year and $X_{i}$ and $Y_{i}$ represent the longitude and latitude coordinates of the geometric center of the class i attribute, respectively.

The formula for calculating the interannual distance of the spatial location of the attribute barycenter is as follows:

$$
\mathrm{D}=\mathrm{C} \times\left[\left(\mathrm{Y}_{\mathrm{s}}-\mathrm{Y}_{\mathrm{k}}\right)^{2}+\left(\mathrm{X}_{\mathrm{s}}-\mathrm{X}_{\mathrm{k}}\right)^{2}\right]^{\frac{1}{2}}
$$

where $\mathrm{D}$ is the distance of the barycenter moving in $\mathrm{S}$ and $\mathrm{K}$ years. $\left(\mathrm{X}_{\mathrm{s}}, \mathrm{Y}_{\mathrm{s}}\right)$ and $\left(\mathrm{X}_{\mathrm{k}}, \mathrm{Y}_{\mathrm{k}}\right)$ represent the longitude and latitude coordinates of the barycenter of some attribute in the S-th and K-th years, respectively. C is a constant value of 111.111, which is the coefficient of converting geographical coordinate units into plane distance.

\subsubsection{Dimensionless Trend}

The climate tendency rate refers to the degree of trend change of a certain climate element in a certain period, representing the changing trend of the meteorological element. In meteorology, a linear tendency is typically used to calculate the climate tendency rate. The NSCA region spans a large east-west area and has significant regional and seasonal variability in agro-climatic resources. Therefore, to eliminate the influence of the mean squared deviation and units of meteorological elements on the magnitude of linear regression coefficient values, we used the dimensionless climate trend. It is particularly suitable for studying and revealing the spatial characteristics of long-term variations in large-scale meteorological fields. Consequently, we could compare the magnitude of trend changes between different geographical locations and meteorological elements.

$$
\begin{gathered}
\mathrm{r}_{\mathrm{xt}}=\frac{\sum_{\mathrm{i}=1}^{\mathrm{n}}\left(\mathrm{x}_{\mathrm{i}}-\overline{\mathrm{x}}\right)(\mathrm{i}-\overline{\mathrm{t}})}{\sqrt{\sum_{\mathrm{i}=1}^{\mathrm{n}}\left(\mathrm{x}_{\mathrm{i}}-\overline{\mathrm{x}}\right)^{2} \sum_{\mathrm{i}=1}^{\mathrm{n}}(\mathrm{i}-\overline{\mathrm{t}})^{2}}} \\
\overline{\mathrm{t}}=\frac{(\mathrm{n}+1)}{2}
\end{gathered}
$$

where $r_{x t}$ is dimensionless trend coefficient with a range of $(-1,1), \mathrm{n}$ is the number of years, $x_{i}$ is the factor value of year $i$ and $\bar{x}$ is the sample mean value. 


\subsubsection{Multiple Linear Regression}

Linear regression is a type of regression analysis that has been extensively studied and widely used in practical applications. It has the advantages of simple methodology, easy implementation and rapid modeling, and it is highly effective for small amounts of data with simple relationships. Multiple linear regression is often used when a dependent variable is affected by several independent variables [38,39].

$\mathrm{Y}_{\mathrm{r}}$ (fluctuation rate of yield)/ $\mathrm{S}_{\mathrm{r}}$ (fluctuation rate of planting area)is the dependent variable, and seasonal dry/wet conditions are the independent variables. After building the relationship model, the significance test is used to test whether the model passes. The goodness of fit $\left(\mathrm{R}^{2}\right)$ is used to describe the effect of regression and determine the interpretation degree of independent variables to dependent variables (Figure 2). In the analysis, the dry/wet conditions in year $i$ affect the fluctuation rate of yield in year $i$ and the fluctuation rate of planting area in year $i+1$.

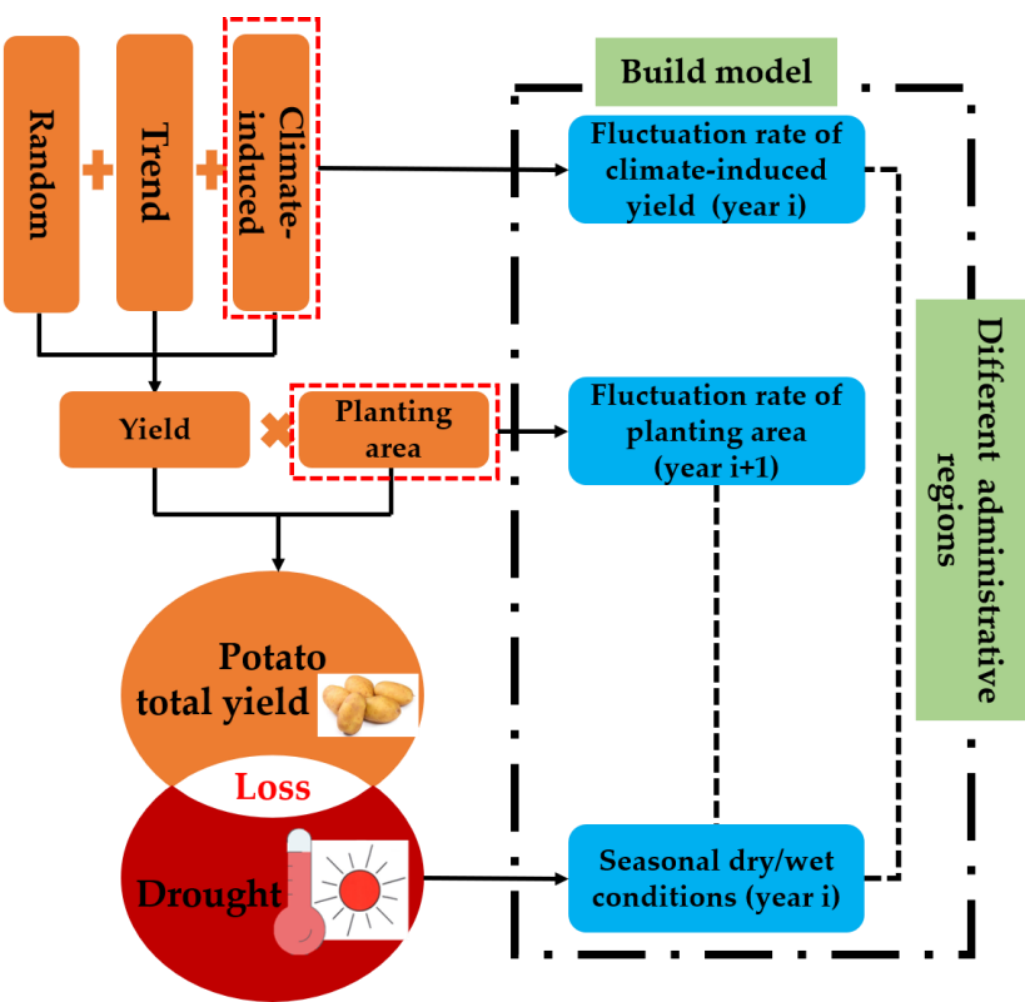

Figure 2. Analysis steps of multiple linear regression.

\subsubsection{Suitability of Agro-Climatic Resources}

Combining the actual situation of the NSCA, meteorological indexes in each growth period of potato and relevant test results, we determined the temperature suitability and precipitation suitability functions.

a. Temperature suitability function.

$$
\begin{gathered}
S t=\frac{\left(t-t_{1}\right)\left(t_{h}-t\right)^{B}}{\left(t_{0}-t_{1}\right)\left(t_{h}-t_{0}\right)^{B}} \\
B=\frac{t_{h}-t_{0}}{t_{0}-t_{1}}
\end{gathered}
$$

where St is the temperature suitability of a certain growth period; $t$ is the daily average temperature in a development period; $t_{1}, t_{h}$ and $t_{0}$ are the lower limit temperature, upper limit temperature and appropriate temperature, respectively, required for each growth period of potato. The three base point temperatures of potato in each growth period are 
determined by referring to the corresponding index system combined with the production practice of NSCA potato (Table 1).

Table 1. Temperature index and crop coefficient of NSCA potato.

\begin{tabular}{cccc}
\hline Growth Stage & $\begin{array}{c}\text { Lower Limit } \\
\text { Temperature }\left({ }^{\circ} \mathbf{C}\right)\end{array}$ & $\begin{array}{c}\text { Optimum } \\
\text { Temperature }\left({ }^{\circ} \mathbf{C}\right)\end{array}$ & $\begin{array}{c}\text { Upper Limit } \\
\text { Temperature }\left({ }^{\circ} \mathbf{C}\right)\end{array}$ \\
\hline Seedling stage & 5 & 16 & $\begin{array}{c}\text { Crop } \\
\text { Coefficient }(\text { Kc })\end{array}$ \\
Tuber growth stage & 7 & 19 & 0.5 \\
Mature stage & 8 & 17 & 30 \\
\hline
\end{tabular}

b. Precipitation suitability function.

$$
\begin{gathered}
\mathrm{R}<\mathrm{Ro}, \mathrm{Sp}=\frac{\mathrm{R}}{\mathrm{Ro}} \\
\mathrm{R} \geq \mathrm{Ro}, \mathrm{Sp}=1
\end{gathered}
$$

where $\mathrm{Sp}$ is the precipitation suitability, $\mathrm{R}$ is the cumulative precipitation in a certain development period of potato and Ro is the crop water demand in each growth period of potato. We refer to the standard crop coefficient of 85 crops recommended by FAO- 56 .

c. Comprehensive suitability formula of temperature and precipitation.

$$
\mathrm{S}=\mathrm{W}_{1} \times \mathrm{St}+\mathrm{W}_{2} \times \mathrm{Sp}
$$

where $S$ is the comprehensive suitability of temperature and precipitation, with a range of $[0,1] . W_{1}$ and $W_{2}$ are weight values of temperature and precipitation suitability. In this study, the weight values calculated by entropy weight method are 0.403 and 0.597 , respectively. According to the natural breakpoint method, the comprehensive suitability index of NSCA potato was divided into (1) unsuitable, [0.075, 0.3), (2) less suitable, [0.3, 0.45), (3) suitable, $[0.45,0.6)$ and (4) highly suitable, $[0.6,0.83)$.

\subsubsection{Data Analysis}

According to the four seasons meteorological division method (a common method used for defining the temperate zone in the Northern Hemisphere), the daily climate data are sorted into quarterly data and year data: (1) from December of the previous year to February of the current year was winter; (2) from March to May was spring; (3) from June to August was summer and (4) from September to November was autumn, as well as (5) annual average. The meteorological data are processed and analyzed with Python 3.8 software. The static and inverse distance interpolation and the median of adjacent days with missing days within 5 years are filled, and the stations with more missing days are deleted. Then, ANUSPLIN 4.3 software (manufacturer the Fenner School of Environment and Society, Australian National University) is used for spatial interpolation according to the elevation data to obtain the meteorological data set with resolution of $0.05^{\circ} \times 0.05^{\circ}$.

\section{Results}

\subsection{Variations of the Dry/Wet Condition}

The absolute values of the coefficients of variation for the seven climate factors ranged from 0.02 to 20.14 (Table A2). The degree of variation is evident in winter and spring and is relatively moderate in summer.

For precipitation and average temperature, the dimensionless climate trend rate analysis shows that there are significant differences between provinces over the seasons. The lowest values of precipitation occur in Gansu province in autumn, and the highest values occur in Xinjiang province in winter. Positive changes are mainly concentrated in the northeast and southwest. Negative changes are mainly concentrated in the central and southern regions. The lowest value of average temperature occurs in Shaanxi Province in summer, and the highest value occurs in Qinghai Province in autumn. Positive changes 
are mainly concentrated in the northeast and most parts of the Xinjiang, southern Gansu and Qinghai provinces. Negative changes occur mainly in central and western Xinjiang. Figure 3 shows that the spatial distribution of the SPEI of the NSCA increases gradually from west to east over the four seasons. Among them, the range of the SPEI in winter is the largest at 0.79 . The lowest values in winter and spring appeared in the southwest of Xinjiang Province, the lowest values in summer appeared in the southeast of Jilin Province and the lowest values in autumn appeared in the middle of Hebei Province. Among the changes of the SPEI in each season, the most obvious is in winter, and the most subtle is in summer. The change trend shows that the drought in winter and spring in the NSCA shows an obvious mitigation trend. However, except for a few areas, the drought in summer and autumn shows an aggravating trend.
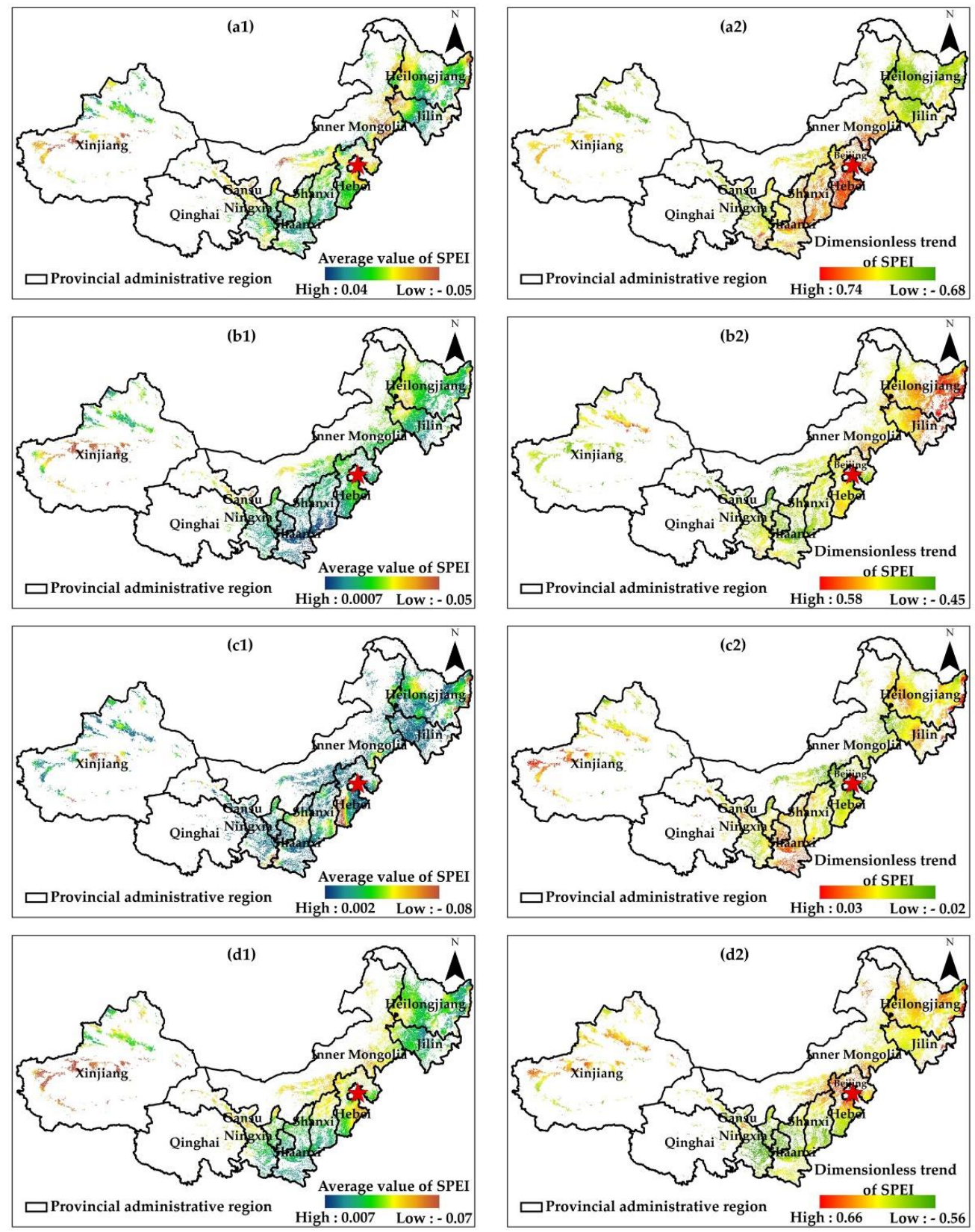

Figure 3. Spatial distribution and dimensionless trend coefficients of SPEI in each season from 1960 to 2019: (a) winter; (b) spring; (c) summer; (d) autumn; (1) average value; (2) dimensionless trend. 


\subsection{Variation of Contribution Factors of Potato Total Yield}

\subsubsection{Spatio-Temporal Variation of Yield Structure}

The NSCA plays an important role in China's potato industry. There were periods of relative increase and decrease in planting area, total yield and yield, and overall, they have shown an increasing trend. However, the NSCA's proportion of the total yield and planting area in China has shown a downward trend (Figure 4).
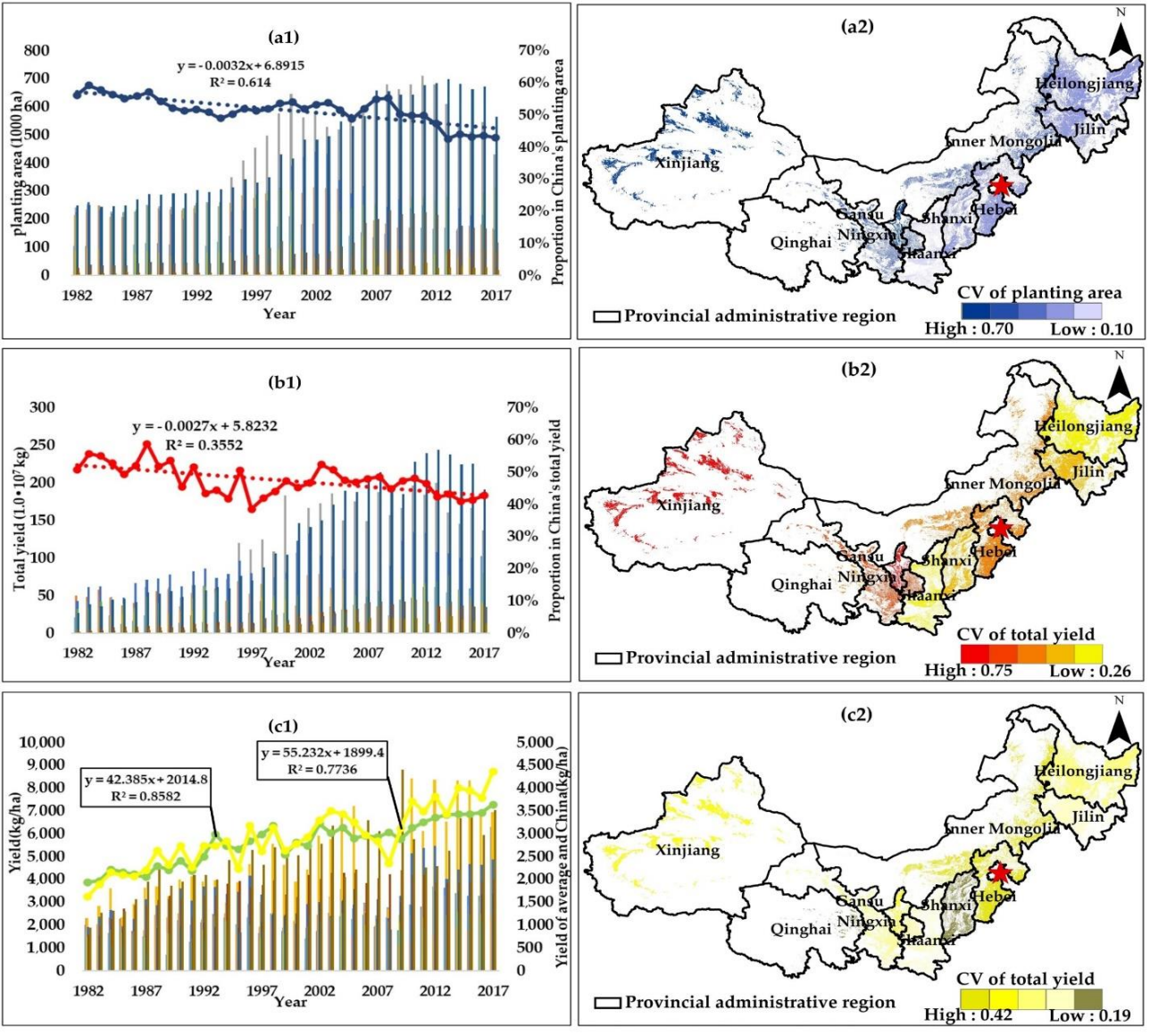

Figure 4. Annual variation and coefficient of variation (CV) of potato yield structure from 1982 to 2017: (a) planting area (1000 ha); (b) total yield $\left(1.0 \times 10^{7} \mathrm{~kg}\right)$; (c) yield $(\mathrm{kg} / \mathrm{ha})$; (1) annual variation; (2) CV.

The proportion of potato planting area in China is declining, but it remains greater than 40\%. Except for 1994 and 2005, the proportion before 2010 was greater than $50 \%$. After 2010, it has gradually decreased to less than 50\%. Except for Shanxi and Jilin, the planting area has increased in the remaining eight sub-regions. Among this, the growth rates for the planting area in Gansu and Inner Mongolia are as high as 8.77 ha/a and $5.27 \mathrm{ha} / \mathrm{a}$, respectively. The planting area of Inner Mongolia and Gansu had an absolute advantage.

The proportion of total yield in China has decreased as a whole, but at present, it is greater than one-third. In 1988, it was over 58\%. In 1997, the most unprecedented drought since the founding of China occurred in the NSCA, which reduced the proportion of total yield to 38\%. The yield of Inner Mongolia, Heilongjiang and Gansu had an absolute advantage. Except for Shanxi, total yield in the remaining nine sub-regions is increasing. The total yields in Gansu, Inner Mongolia and Hebei increased by $4.57 \times 10^{7} \mathrm{~kg} / \mathrm{a}, 2.67 \times 10^{7} \mathrm{~kg} / \mathrm{a}$ and $2.27 \times 10^{7} \mathrm{~kg} / \mathrm{a}$, respectively.

The yield of the NSCA, which is higher than the yield of China, is on the rise. However, there is a marked gap in the yield of the different administrative units in the NSCA. The yield in Qinghai and Xinjiang had an absolute advantage. Except for Shanxi, the remaining 
nine sub-regions showed an increasing state. The results showed that the rates of yield in Xinjiang, Jilin and Hebei were $142.89 \mathrm{~kg} / \mathrm{ha}, 128.93 \mathrm{~kg} / \mathrm{ha}$ and $119.18 \mathrm{~kg} / \mathrm{ha}$, respectively. The coefficient of variation showed that the yield in Hebei had the largest change range and highest fluctuation. The change range was the smallest in Shaanxi.

\subsubsection{Shift of Barycenter of Yield Structure and Population}

Using the barycenter model, we obtained the barycenter of potato yield structure factors and population in different decades (Figure 5). In the past 36 years, the barycenter shifts of total yield, planting area, yield and population in the NSCA were different and apparent. Except for the total production center in 1982, located in the northwest of Hebei Province, other centers were in the central and western parts of Inner Mongolia. The distance of barycenter shifts for total yield, planting area, yield and population were $315,313 \mathrm{~m}, 288,369 \mathrm{~m}, 106,166 \mathrm{~m}$ and $89,821 \mathrm{~m}$, respectively. The shift in the barycenter of the total yield is approximately 3 times the yield and 3.5 times the population. All four barycenters moved to the west of the NSCA.

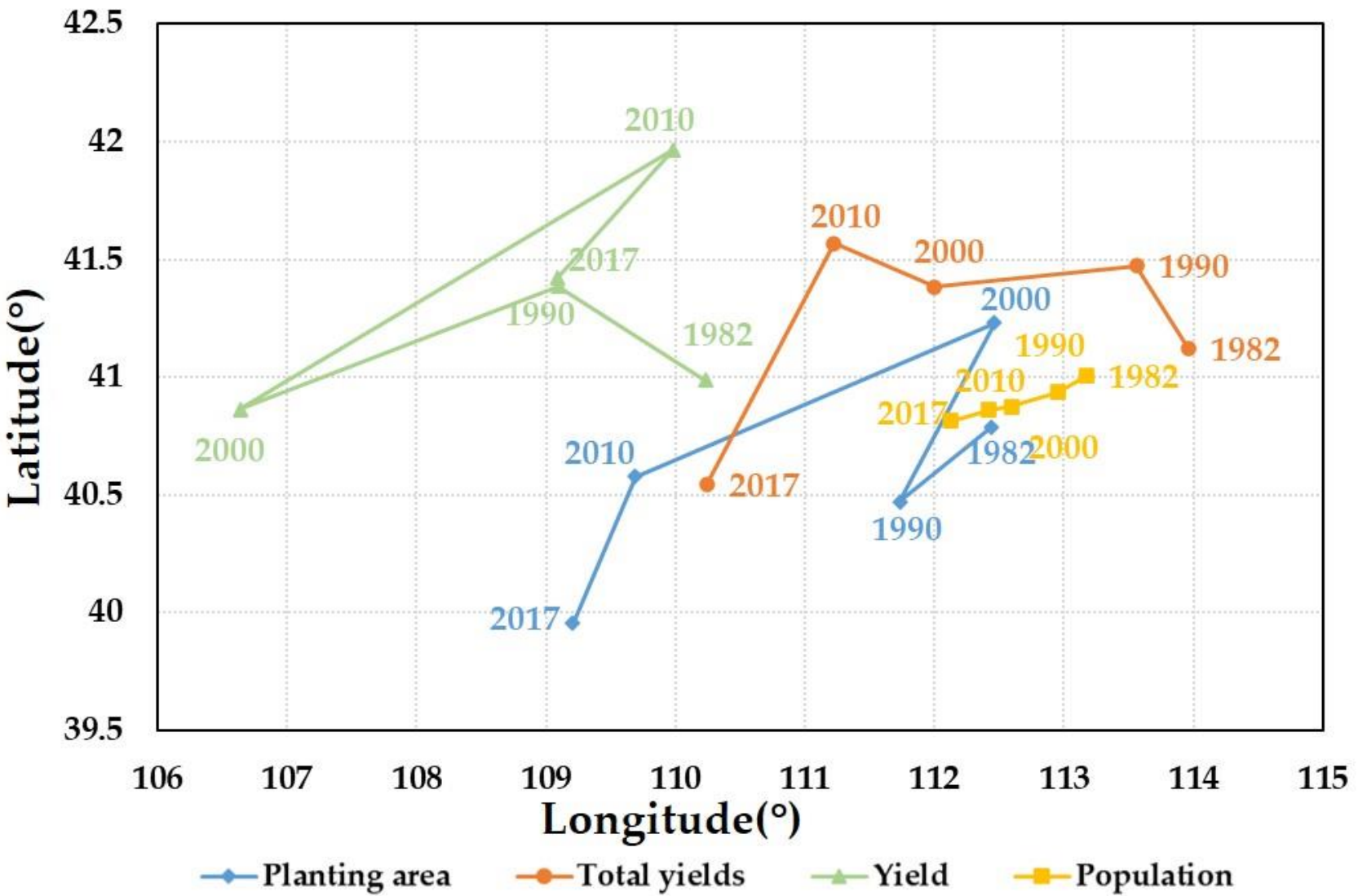

Figure 5. Shift of barycenter of yield structure and population from 1982 to 2017.

\subsubsection{Evolution of Contribution Factors}

Based on the analysis of contributing factors (Figure 6) of the total yield change in the NSCA over the past 36 years, it was found that the contribution characteristics of planting area and yield to the total yield were markedly different with both positive and negative values. The total yield of the NSCA was dominated by the yield. However, time scale analysis results revealed that the contribution rate of the yield showed a downward trend, while the contribution rate of the planting area showed an upward trend. The contribution rates of yield in the 1980s and 2000s were as high as $86.98 \%$ and $91.94 \%$, respectively, which became the leading factor of total yield change in the current period. The planting area contribution rates in the 1990 s and 2010 s were $100.94 \%$ and $1020.60 \%$, respectively, which were the main factors affecting the total yield change. 


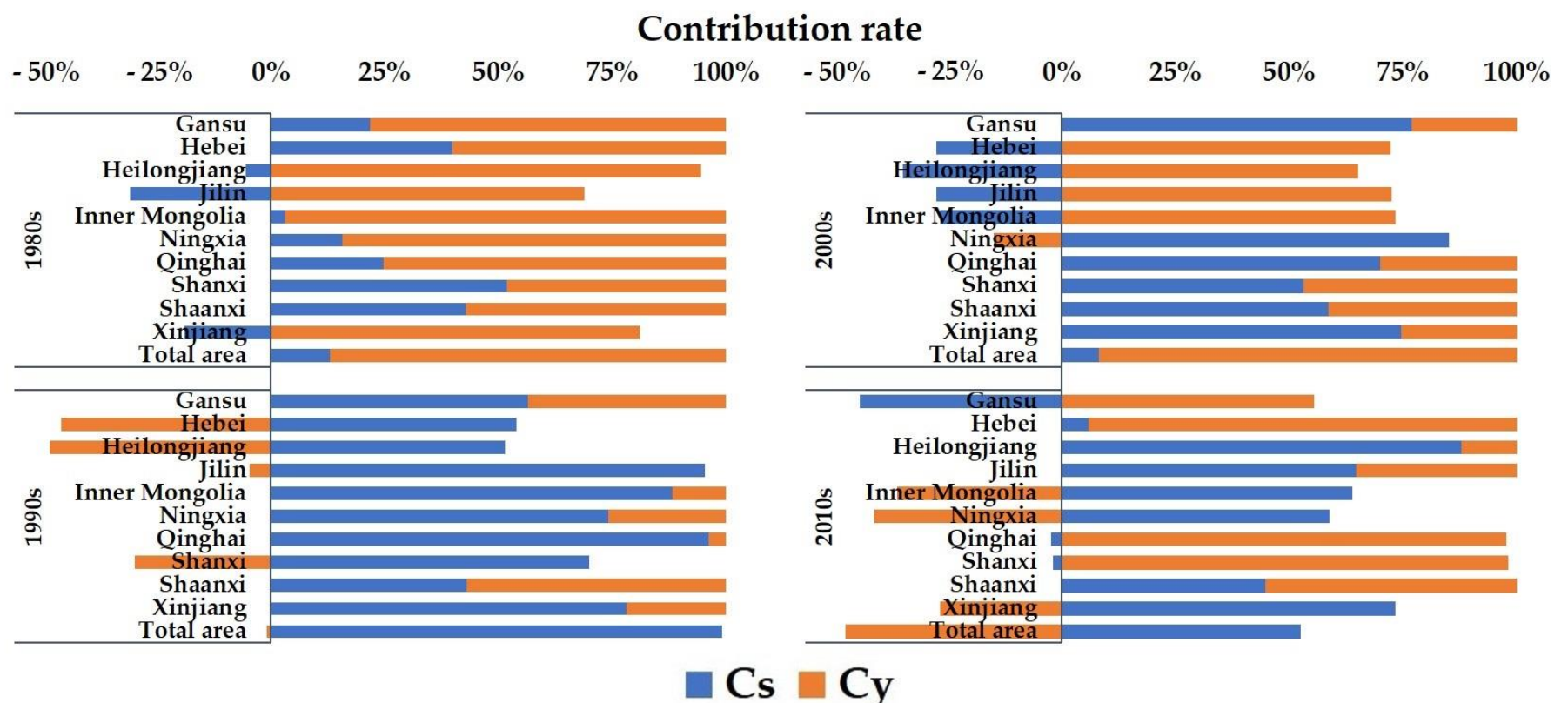

Figure 6. Evolution of contribution factors from 1960 to 2017: (1980s) 1982-1990; (1990s) 1991-2000; (2000s) 2001-2010; (2010s) 2011-2017; (total) 1982-2017.

Different administrative regions, except for Qinghai and Shanxi, were dominated by yield. The contribution rate of yield of Heilongjiang and Jilin was more than $150 \%$, while that of Shanxi was $-23.75 \%$. In the time scale analysis, Heilongjiang, Hebei, Gansu, Shanxi and Qinghai showed a downward trend, while Ningxia, Inner Mongolia, Xinjiang, Jilin, Shaanxi and the whole NSCA showed an upward trend. The contribution rate of yield showed an opposite trend. The changes in contribution rate by a large margin in Gansu, Inner Mongolia, Ningxia, Qinghai, Shaanxi and Xinjiang in the 2010s are in line with establishing potato seed bases and policy support. Notably, the three administrative regions of Inner Mongolia, Ningxia and Xinjiang were dominated by the contribution rate of the planting area.

\subsection{Model Building between Dry/Wet Conditions and Change of Contribution Factors of Potato Total Yield}

In this study, the SPEIs of the four seasons were used as independent variables to fit the fluctuation rate of yield $\left(\mathrm{Y}_{\mathrm{r}}\right)$ in the current year and the fluctuation rate of planting area $\left(\mathrm{S}_{\mathrm{r}}\right)$ in the next year (Table 2). Besides the agricultural provinces, Heilongjiang and Jilin, and the main seed-potato-producing areas, Gansu and Ningxia, the annual comprehensive interpretation rates of dry/wet conditions for the change of yield passed the significance test of 0.05 , and the interpretation amounts were greater than $50 \%$. Data analysis showed that although summer and autumn were the main growing seasons of potato, the dry/wet conditions of all four seasons had in impact on the yield.

Except for Heilongjiang and Jilin, the annual comprehensive explanation rates of dry/wet conditions for the change in planting area passed the significance test of 0.05 , and the explanation amounts were greater than $50 \%$. It should be noted that although the yield of Qinghai and Xinjiang is high, the response to dry/wet conditions is not obvious compared with other provinces because of the small planting area and the small amount of data. 
Table 2. Fitting equation between dry/wet conditions and fluctuation rate of yield/planting area: (a) winter; (b) spring; (c) summer; (d) autumn.

\begin{tabular}{clc}
\hline Sub-Region & $\mathbf{R}^{2}$ & Fitting Equation \\
\hline Gansu & 0.46 & $\mathrm{Yr}=-433.516-89.22 \mathrm{a}+23.79 \mathrm{~b}+160.53 \mathrm{c}-138.15 \mathrm{~d}$ \\
& 0.58 & $\mathrm{Sr}=444.91+10295 \mathrm{a}-14.07 \mathrm{~b}-154.94 \mathrm{c}+123.92 \mathrm{~d}$ \\
Hebei & 0.56 & $\mathrm{Yr}=17.21+39.6 \mathrm{a}-17.23 \mathrm{~b}-19.18 \mathrm{c}+7.29 \mathrm{~d}$ \\
& 0.51 & $\mathrm{Sr}=143.3+8.91 \mathrm{a}-17.23 \mathrm{~b}-19.18 \mathrm{c}+7.29 \mathrm{~d}$ \\
Heilongjiang & 0.54 & $\mathrm{Yr}=-246.51-31.65 \mathrm{a}+89.71 \mathrm{~b}+86.45 \mathrm{c}+1.55 \mathrm{~d}$ \\
Inner Mongolia & 0.45 & $\mathrm{Sr}=255.9+15.40 \mathrm{a}-42.69 \mathrm{~b}-63.36 \mathrm{c}-16.04 \mathrm{~d}$ \\
& 0.55 & $\mathrm{Y}=-16.59+15.15 \mathrm{a}-166.95 \mathrm{~b}+382.75 .48 \mathrm{c}-290.98 \mathrm{~d}$ \\
Jilin & 0.62 & $\mathrm{Sr}=423.46+98.9 \mathrm{a}-143.62 \mathrm{~b}-196.51 \mathrm{c}+9.71 \mathrm{~d}$ \\
& 0.35 & $\mathrm{Yr}=64.85-215.82 \mathrm{a}-6.09 \mathrm{~b}+515.02 \mathrm{c}+613.80 \mathrm{~d}$ \\
Ningxia & 0.45 & $\mathrm{Sr}=84.42-3.45 \mathrm{a}+1.64 \mathrm{~b}+2.98 \mathrm{c}-14.35 \mathrm{~d}$ \\
& 0.48 & $\mathrm{Yr}=14.81+40.98 \mathrm{a}+28.18 \mathrm{~b}+214.22 \mathrm{c}+50.29 \mathrm{~d}$ \\
Qinghai & 0.63 & $\mathrm{Sr}=108.36-9.17 \mathrm{a}-35.19 \mathrm{~b}-63.82 \mathrm{c}+34.2 \mathrm{~d}$ \\
& 0.52 & $\mathrm{Yr}=-5.62+85.81 \mathrm{a}+67.06 \mathrm{~b}+12.17 \mathrm{c}+54.35 \mathrm{~d}$ \\
Shaanxi & 0.51 & $\mathrm{Sr}=57.16-4.05 \mathrm{a}-8.1 \mathrm{~b}-3.3 \mathrm{c}+8.47 \mathrm{~d}$ \\
Shanxi & 0.53 & $\mathrm{Yr}=-20.3+14.89 \mathrm{a}-53.89 \mathrm{~b}+309.84 \mathrm{c}+2.4 \mathrm{~d}$ \\
Xinjiang & 0.54 & $\mathrm{Sr}=266.12-12.71 \mathrm{a}+5.88 \mathrm{~b}-32.75 \mathrm{c}-2.3 \mathrm{~d}$ \\
& 0.61 & $\mathrm{Yr}=23.7+110.69 \mathrm{a}+76.04 \mathrm{~b}+422.06 \mathrm{c}+96.5 \mathrm{~d}$ \\
& 0.53 & $\mathrm{Sr}=233.42+6.56 \mathrm{a}-29.95 \mathrm{~b}-10.54 \mathrm{c}-21.25 \mathrm{~d}$ \\
& 0.53 & $\mathrm{Yr}=15.31+151.74 \mathrm{a}+218.15 \mathrm{~b}-396.1 \mathrm{c}+342.72 \mathrm{~d}$ \\
\hline
\end{tabular}

Note: number in the red box failed the significance test of 0.05 .

\section{Discussion}

\subsection{Effect of Seasonal Dry/Wet Conditions on NSCA Potato at the Provincial Level}

The results of the model of different administrative regions during different seasons showed that: (1) dry/wet conditions before and during the planting of potato affected not only the harvest yield but also the increase or decrease of planted area. This is because under different environmental conditions, such as dry/wet conditions, farmers will try different adaptations to increase yields-for example, improvements in field management practices and increases in planting area $[25,26]$. The NSCA, in arid and semi-arid regions, spans a wide range from left to right, with a rich diversity of agro-climatic resources. The relationship between dry/wet conditions and total potato production varies from province to province; (2) Jilin and Heilongjiang are important agricultural provinces in China. Conditions such as fertile black land, fewer pests and diseases, climate and topography, social and economic conditions and the Sickle Bay Area policy to reduce maize area have had a major positive impact on potato production. With the advantages of cultivated land resources and climatic conditions, Gansu and Ningxia have developed a complete modern potato breeding and production system with high stability, supported by the Sickle Bay Area policy and targeted poverty alleviation policies $[40,41]$. Thus, potato production in these four provinces is less affected by dry/wet conditions than in other areas of the NSCA.

\subsection{Problems Needing Attention Regarding NSCA Potato}

The spatial and temporal variabilities of agro-climatic resources determine the distribution of potato varieties, the structure of agricultural production and commercial practices [42,43]. Agricultural practices in developing countries, including China, "Kao Tian Chi Fan", are too traditional and outdated, and farmers have limited knowledge. NSCA potato-growing areas are concentrated in rain-fed agricultural areas with poor irrigation conditions. From 1990, the total yield was increased by increasing the planting area in the west. However, the conflict between population and cultivated land resources is becoming more and more prominent. There is less and less room for the development of crops to meet the yield demand by increasing the planting area. Changing the current situation to total production growth, which focuses on expanding planting area, fully recognizing other advantages such as agro-climatic resources, reducing the pressure from the 
demand for increased crop production and developing efficient agriculture are important issues facing developing countries, including China [44-46]. Therefore, we analyzed the problems in NCSA potato production since 1982 in terms of climatic resource conditions, land use/cover change (LUCC) and social status.

Heat resources $\left(>10^{\circ} \mathrm{C}\right.$ cumulative temperature) and precipitation resources combined with NSCA topography were selected to represent agro-climatic resources for the last 60 years for fine climate zoning analysis of potato cultivation (Figure 7). Agro-climatic resources have obvious regional unevenness because of the large east-west span and complex topography. Precipitation resources show an increasing trend from north to south and west to east, with the lowest amount of precipitation in the northwest. The suitability of precipitation increases from west to east and from north to east. The highest values are mostly concentrated in Qinghai, Gansu, Jilin and southeastern Heilongjiang. The heat resource decreases from west to east and from central to north/south. The high values of temperature suitability are distributed in the central region. Refined climate zoning over the last 60 years has shown that most of the NSCA can meet the climatic resource conditions required for potato. The high-planting-suitability areas are mainly located in the eastern and central parts of the country and have gradually expanded in the last 30 years. The LUCC of the NSCA for the period of 1980-2020 (Figure 8) shows that the main source of the increase in cultivated land is grassland. As an important ecological barrier in northern China, the grassland in the NSCA plays an extremely important role in windbreak and sand fixation, soil and water conservation, air purification and climate regulation, etc. The reduction of its area will bring serious ecological security problems to the NSCA or even to China. The mid-western regions of the NSCA have most of China's reserve resources of cultivated land, and policies such as the "Western Development" policy have shifted the center of potato production in the NSCA westward. The northeastern plains (Jilin, Heilongjiang, central-eastern Inner Mongolia) are the main grain-crop (maize, rice, soybeans)-exporting region in China and are experiencing increasing population loss $[47,48]$.
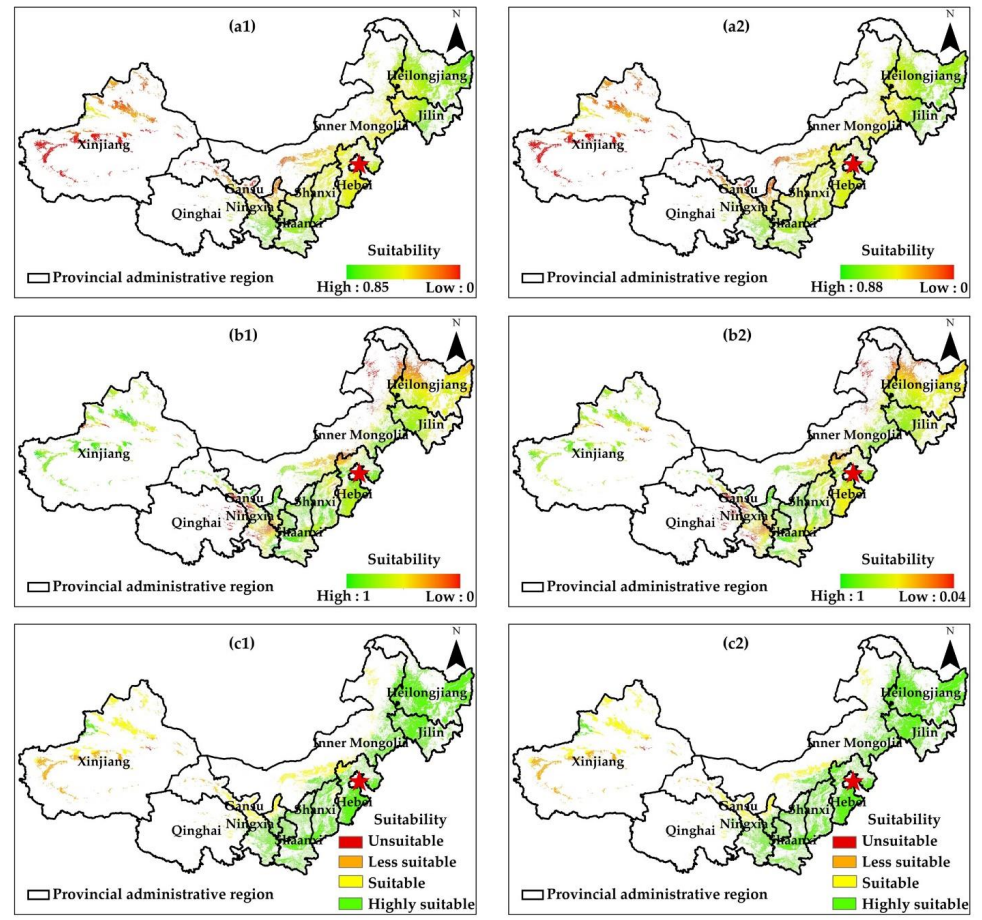

Figure 7. Distribution of agro-climatic resources suitability and refined climatic regionalization of NSCA potato from 1960 to 2019: (a) precipitation suitability; (b) temperature suitability; (c) climatic regionalization; (1) 1960-1989; (2) 1990-2019. 


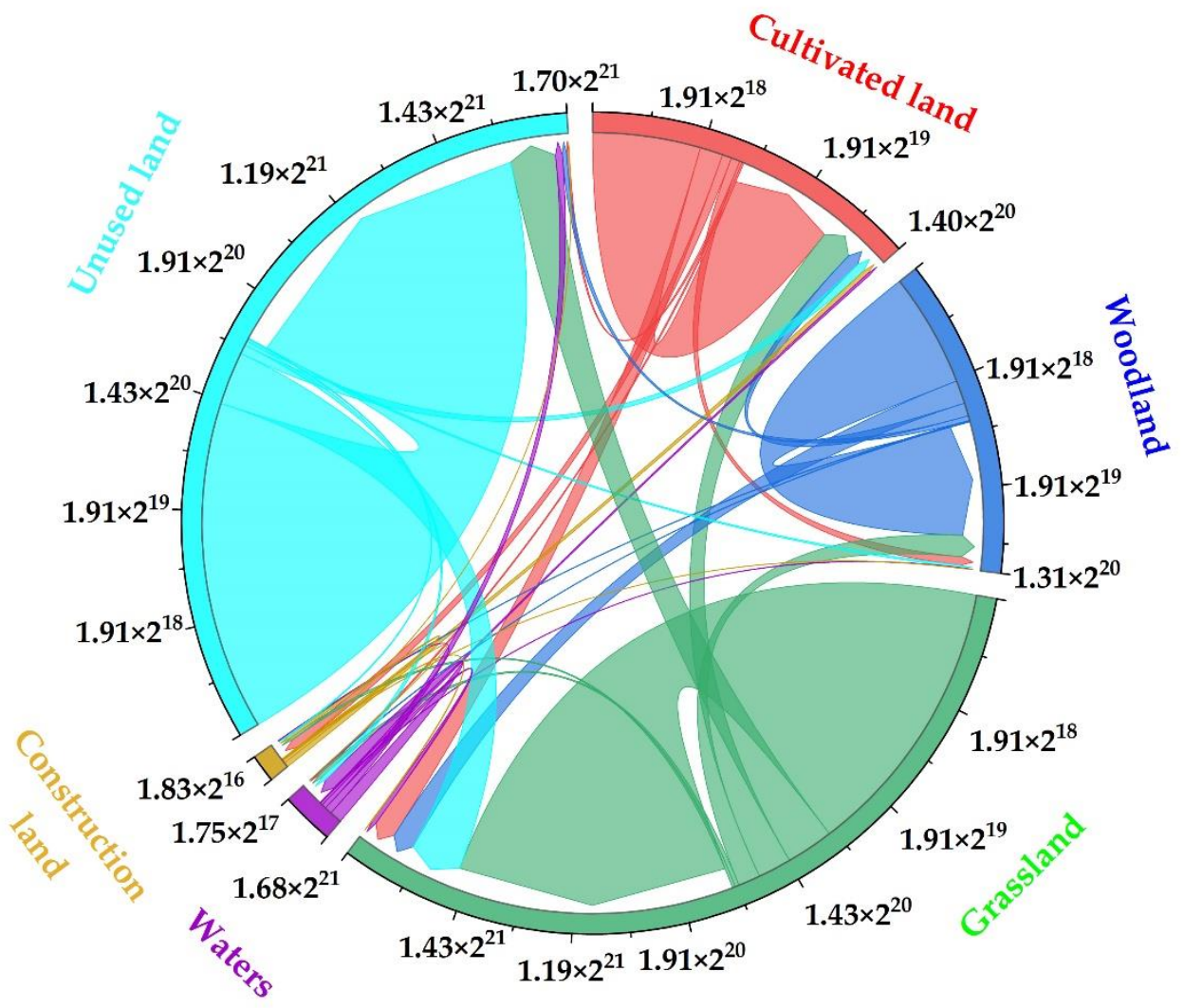

Figure 8. Chord diagram of land use/cover change from 1980 to 2020.

Combining these issues, it is clear that the West has been a hot spot for potato cultivation in the NSCA in recent years, but this ignores the improvement of planting suitability in the east. Thus, planting areas, high-production areas and high-suitability areas have failed to overlap well and yields have tended to stabilize. Dry/wet conditions in northern China will be dominated by severe and extreme seasonal drought events over the next 40 years [49]. Based on our research results, it is suggested that the government and scholars: (1) strengthen communication with smallholder farmers and carry out more training lectures on basic agricultural knowledge, (2) preferably overlap high-yield areas, highsuitability areas and planting areas and (3) ensure that potato-related statistical research work is detailed and comprehensive to improve the basic ability of disaster prevention and reduction. Our research results have a certain reference value for the sustainable production of potato in the NSCA and China in the future.

\section{Conclusions}

In this study, we systematically analyzed the characteristics of dry/wet conditions and changes in potato total yield, constructed a relationship model between seasonal dry/wet conditions and the contribution factors to total yield changes in different administrative regions and discussed the issues in production over many years that need attention in the main potato-producing area of China. The relationship model showed that dry/wet conditions during non-growth periods also affected yield to different degrees. Under conditions of increased potato planting suitability in the east and middle regions of the NSCA, the main factor influencing total yield shifted from yield to planting area, with the grassland in the southwest being the main source. This situation leads to the problem of high-yield area, high-suitability area and planting area not overlapping.

In recent years, China's agricultural production has been limited by the shortage of cultivated land reserve resources and the increasing frequency of meteorological disasters. The NSCA potato-growing area is in urgent need of appropriate land use planning layout and management measures. 
Author Contributions: All authors contributed meaningfully to this study. Conceptualization, D.R.; methodology, D.R. and S.G.; software, D.R., K.L. and X.L.; validation, D.R., J.X. and M.Z.; formal analysis, D.R.; investigation, D.R. and S.G.; resources, D.R.; data curation, D.R., K.L. and S.G.; writing-original draft preparation, D.R.; writing—review and editing, X.L. and J.Z.; visualization, D.R., J.X. and M.Z.; supervision, X.L. and J.Z.; project administration, D.R. and J.Z.; funding acquisition, J.Z. All authors have read and agreed to the published version of the manuscript.

Funding: This research was funded by the National Key Research and Development Program of China (2019YFD1002201); the National Natural Science Foundation of China (41877520); the Science and Technology Development Plan of Jilin Province (20190303018SF); the Key Research and Projects Development Plan of Jilin Province (20200403065SF); and the Science and Technology Plan of Changchun (19SS007).

Institutional Review Board Statement: Not applicable.

Informed Consent Statement: Not applicable.

Data Availability Statement: Not applicable.

Acknowledgments: We appreciate the editors and the reviewers for their constructive suggestions and insightful comments, which helped to greatly improve this manuscript. We also would like to thank the China Meteorological Administration for providing the historical climate data.

Conflicts of Interest: The authors declare no conflict of interest.

\section{Appendix A}

Table A1. Correlation and significance test of trend yield and actual yield in different administrative units of the NSCA from 1982 to 2017.

\begin{tabular}{cccc}
\hline Sub-Region & $\mathbf{R}^{\mathbf{2}}$ & $\mathbf{F}$ & Sig \\
\hline Gansu & 0.97 & 556.22 & 0.00 \\
Hebei & 0.84 & 81.84 & 0.00 \\
Heilongjiang & 0.84 & 78.23 & 0.00 \\
Inner Mongolia & 0.77 & 48.53 & 0.00 \\
Jilin & 0.75 & 42.34 & 0.00 \\
Ningxia & 0.88 & 119.15 & 0.00 \\
Qinghai & 0.93 & 203.17 & 0.00 \\
Shaanxi & 0.74 & 40.91 & 0.00 \\
Shanxi & 0.55 & 15.06 & 0.00 \\
Xinjiang & 0.84 & 79.12 & 0.00 \\
\hline
\end{tabular}

Table A2. Coefficients of variation of different climatic factors in different administrative units of the NSCA from 1960 to 2019: (a) winter; (b) spring; (c) summer; (d) autumn; (1) seasonal average temperature; (2) seasonal maximum temperature; (3) seasonal minimum temperature; (4) seasonal precipitation; (5) seasonal average relative humidity; (6) seasonal average sunshine hours; (7) seasonal average wind speed.

\begin{tabular}{|c|c|c|c|c|c|c|c|c|}
\hline Sub-Region & Season & 1 & 2 & 3 & 4 & 5 & 6 & 7 \\
\hline \multirow{4}{*}{ Gansu } & $\mathrm{a}$ & 0.20 & 0.82 & 0.10 & 0.34 & 0.08 & 0.05 & 0.10 \\
\hline & $\mathrm{b}$ & 0.10 & 0.06 & 0.38 & 0.29 & 0.09 & 0.06 & 0.09 \\
\hline & C & 0.04 & 0.03 & 0.07 & 0.18 & 0.04 & 0.05 & 0.11 \\
\hline & $\mathrm{d}$ & 0.11 & 0.07 & 0.49 & 0.27 & 0.06 & 0.06 & 0.10 \\
\hline \multirow{4}{*}{ Hebei } & $\mathrm{a}$ & 0.28 & 0.73 & 0.15 & 0.67 & 0.10 & 0.10 & 0.18 \\
\hline & $\mathrm{b}$ & 0.09 & 0.06 & 0.20 & 0.40 & 0.09 & 0.07 & 0.14 \\
\hline & c & 0.03 & 0.03 & 0.04 & 0.23 & 0.04 & 0.10 & 0.10 \\
\hline & $\mathrm{d}$ & 0.07 & 0.05 & 0.17 & 0.36 & 0.05 & 0.09 & 0.13 \\
\hline
\end{tabular}


Table A2. Cont.

\begin{tabular}{|c|c|c|c|c|c|c|c|c|}
\hline Sub-Region & Season & 1 & 2 & 3 & 4 & 5 & 6 & 7 \\
\hline \multirow{4}{*}{ Heilongjiang } & $\mathrm{a}$ & 0.10 & 0.16 & 0.08 & 0.40 & 0.05 & 0.06 & 0.13 \\
\hline & $\mathrm{b}$ & 0.34 & 0.13 & 0.50 & 0.28 & 0.06 & 0.05 & 0.13 \\
\hline & c & 0.04 & 0.03 & 0.06 & 0.18 & 0.04 & 0.09 & 0.12 \\
\hline & $\mathrm{d}$ & 0.39 & 0.13 & 0.40 & 0.31 & 0.05 & 0.07 & 0.12 \\
\hline \multirow{4}{*}{ Inner Mongolia } & $\mathrm{a}$ & 0.11 & 0.23 & 0.08 & 0.30 & 0.07 & 0.03 & 0.14 \\
\hline & $\mathrm{b}$ & 0.21 & 0.09 & 0.94 & 0.28 & 0.07 & 0.03 & 0.12 \\
\hline & c & 0.04 & 0.03 & 0.06 & 0.18 & 0.06 & 0.04 & 0.10 \\
\hline & $\mathrm{d}$ & 0.23 & 0.09 & 0.62 & 0.27 & 0.04 & 0.04 & 0.11 \\
\hline \multirow{4}{*}{ Jilin } & $\mathrm{a}$ & 0.13 & 0.26 & 0.10 & 0.39 & 0.06 & 0.05 & 0.14 \\
\hline & $\mathrm{b}$ & 0.19 & 0.10 & 20.14 & 0.23 & 0.05 & 0.06 & 0.13 \\
\hline & c & 0.03 & 0.03 & 0.05 & 0.16 & 0.03 & 0.08 & 0.11 \\
\hline & $\mathrm{d}$ & 0.16 & 0.09 & 5.04 & 0.27 & 0.04 & 0.07 & 0.12 \\
\hline \multirow{4}{*}{ Ningxia } & $\mathrm{a}$ & 0.23 & 1.06 & 0.13 & 0.53 & 0.10 & 0.07 & 0.12 \\
\hline & $\mathrm{b}$ & 0.11 & 0.07 & 0.37 & 0.45 & 0.12 & 0.06 & 0.11 \\
\hline & c & 0.04 & 0.03 & 0.06 & 0.28 & 0.06 & 0.07 & 0.12 \\
\hline & $\mathrm{d}$ & 0.10 & 0.07 & 0.37 & 0.35 & 0.08 & 0.08 & 0.13 \\
\hline \multirow{4}{*}{ Qinghai } & $\mathrm{a}$ & 0.12 & 2.58 & 0.08 & 0.34 & 0.09 & 0.04 & 0.13 \\
\hline & $\mathrm{b}$ & 0.30 & 0.09 & 0.23 & 0.17 & 0.06 & 0.03 & 0.12 \\
\hline & c & 0.07 & 0.05 & 0.17 & 0.11 & 0.03 & 0.06 & 0.11 \\
\hline & $\mathrm{d}$ & 0.51 & 0.09 & 0.26 & 0.20 & 0.05 & 0.04 & 0.11 \\
\hline \multirow{4}{*}{ Shaanxi } & $\mathrm{a}$ & 1.67 & 0.25 & 0.19 & 0.42 & 0.08 & 0.13 & 0.11 \\
\hline & $\mathrm{b}$ & 0.07 & 0.07 & 0.10 & 0.28 & 0.08 & 0.10 & 0.10 \\
\hline & $\mathrm{C}$ & 0.03 & 0.03 & 0.03 & 0.18 & 0.04 & 0.11 & 0.11 \\
\hline & $\mathrm{d}$ & 0.06 & 0.06 & 0.12 & 0.34 & 0.05 & 0.15 & 0.10 \\
\hline \multirow{4}{*}{ Shanxi } & $\mathrm{a}$ & 0.27 & 0.67 & 0.13 & 0.52 & 0.11 & 0.11 & 0.15 \\
\hline & $\mathrm{b}$ & 0.10 & 0.07 & 0.26 & 0.36 & 0.12 & 0.08 & 0.11 \\
\hline & c & 0.03 & 0.03 & 0.04 & 0.22 & 0.05 & 0.09 & 0.08 \\
\hline & $\mathrm{d}$ & 0.09 & 0.06 & 0.25 & 0.33 & 0.06 & 0.10 & 0.12 \\
\hline \multirow{4}{*}{ Xinjiang } & $\mathrm{a}$ & 0.15 & 0.52 & 0.11 & 0.36 & 0.04 & 0.07 & 0.11 \\
\hline & $\mathrm{b}$ & 0.11 & 0.07 & 0.31 & 0.26 & 0.07 & 0.05 & 0.11 \\
\hline & c & 0.03 & 0.02 & 0.05 & 0.21 & 0.05 & 0.03 & 0.11 \\
\hline & $\mathrm{d}$ & 0.12 & 0.07 & 0.61 & 0.25 & 0.04 & 0.04 & 0.11 \\
\hline
\end{tabular}

\section{References}

1. Guga, S.; Xu, J.; Riao, D.; Han, A.; Zhang, J. Combining MaxEnt model and landscape pattern theory for analyzing interdecadal variation of sugarcane climate suitability in Guangxi, China. Ecol. Indic. 2021, 131, 108152. [CrossRef]

2. FAOSTAT. Statistical Database of the Food and Agricultural Organization of the United Nation 2018. Available online: http: / / faostat3.fao.org/ (accessed on 25 August 2020).

3. Li, P.H. Potato Physiology; Academic Press: Cambridge, MA, USA, 1985; pp. 1-602.

4. Haas, B.J.; Kamoun, S.; Zody, M.C.; Jiang, R.H.Y.; Handsaker, R.E.; Cano, L.M.; Grabherr, M.; Kodira, C.D.; Raffaele, S.; Tort Alalibo, T.; et al. Genome sequence and analysis of the Irish potato famine pathogen Phytophthora infestans. Nature 2009, 461, 393-398. [CrossRef] [PubMed]

5. Chakraborty, S.; Chakraborty, N.; Datta, A. Increased nutritive value of transgenic potato by expressing a nonallergenic seed albumin gene from Amaranthus hypochondriacus. Proc. Natl. Acad. Sci. USA 2000, 97, 3724-3729. [CrossRef] [PubMed]

6. Zhang, H.; Fen, X.; Yu, W.; Hu, H.-H.; Dai, X.-F. Progress of potato staple food research and industry development in China. J. Integr. Agric. 2017, 16, 2924-2932. [CrossRef]

7. Zhao, J.; Zhang, Y.; Qian, Y.; Pan, Z.; Zhu, Y.; Zhang, Y. Coincidence of variation in potato yield and climate in northern China. Sci. Total Environ. 2016, 573, 965-973. [CrossRef] [PubMed]

8. Meng, Q.; Wang, H.; Yan, P.; Pan, J.; Lu, D.; Cui, Z.; Zhang, F.; Chen, X. Designing a new cropping system for high productivity and sustainable water usage under climate change. Sci. Rep. 2017, 7, 41587. [CrossRef] [PubMed]

9. Daccache, A.; Weatherhead, E.K.; Stalham, M.A.; Knox, J.W. Impacts of climate change on irrigated potato production in a humid climate. Agric. For. Meteorol. 2011, 151, 1641-1653. [CrossRef]

10. Zhang, S.H.; Xu, X.F.; Sun, Y.M.; Zhang, J.L.; Li, C.Z. Influence of drought hardening on the resistance physiology of potato seedlings under drought stress. J. Integr. Agric. 2018, 17, 336-347. [CrossRef]

11. Hijmans, R.J. The effect of climate change on global potato production. Am. J. Potato Res. 2003, 80, 271-279. [CrossRef]

12. Raymundo, R.; Asseng, S.; Robertson, R.; Petsakos, A.; Hoogenboom, G.; Quiroz, R. Climate change impact on global potato production. Eur. J. Agron. 2017, 100, 87-98. [CrossRef] 
13. Shimoda, S.; Kanno, H.; Hirota, T. Time series analysis of temperature and rainfall-based weather aggregation reveals significant correlations between climate turning points and potato (Solanum tuberosum L) yield trends in Japan. Agric. For. Meteorol. 2018, 263, 147-155. [CrossRef]

14. China Meteorological Administration. Yearbook of Meteorological Disasters in China; China Meteorolog Press: Beijing, China, 2019.

15. The Central People's Government of the People's Republic of China. More Than 98\% of the Agricultural Business Entities in China Are Still Smallholder Farmers 2019. Available online: http://www.gov.cn/xinwen/2019--03/01/content_5369810 (accessed on 15 December 2019).

16. Yang, X.; Chen, F.; Lin, X.; Liu, Z.; Zhang, H.; Zhao, J.; Li, K.; Ye, Q.; Li, Y.; Lv, S.; et al. Potential benefits of climate change for crop productivity in China. Agric. For. Meteorol. 2015, 208, 76-84. [CrossRef]

17. Rosegrant, M.W.; Cline, S.A. Global food security: Challenges and policies. Science 2003, 302, 1917-1919. [CrossRef] [PubMed]

18. Wang, N.; Reidsma, P.; Pronk, A.A.; Wit, A.J.W.; van Ittersum, M.K. Can potato add to China's food self-sufficiency? The scope for increasing potato production in China. Eur. J. Agron. 2018, 101, 20-29. [CrossRef]

19. Wang, Y.D.; Liu, X.; Ren, G.; Yang, G.; Feng, Y. Analysis of the spatiotemporal variability of droughts and the effects of drought on potato production in northern China. Agric. For. Meteorol. 2019, 264, 334-342. [CrossRef]

20. Jansky, S.H.; Jin, L.P.; Xie, K.Y.; Xie, C.H.; Spooner, D.M. Potato production and breeding in China. Potato Res. 2009, 52, 57. [CrossRef]

21. Wang, C.; Shi, X.; Liu, J.; Zhao, J.; Bo, X.; Chen, F. Interdecadal variation of potato climate suitability in China. Agric. Ecosyst. Environ. 2021, 310, 107293. [CrossRef]

22. Jin, L.X.; Li, Y.; Li, D.; Yan, W.; Wu, X. Suitability analysis of key potato growth stages in Inner Mongolia under climate change. Chin. J. Eco-Agric. 2018, 26, 38-48.

23. Zhang, Y.; Feng, R.; Nie, W.; Wang, F.; Feng, S. Plastic Film Mulch Performed Better in Improving Heat Conditions and Drip Irrigated Potato Growth in Northwest China than in Eastern China. Water 2020, 12, 2906. [CrossRef]

24. Wang, Y.L.; Hou, Q.; Miao, B.L.; Yun, W.L.; Jia, C.Z. Risk regionalization of drought disaster at flowering stage of potato in Inner Mongolia. J. Arid Meteorol. 2017, 35, 745-750.

25. Lybbert, T.J.; Sumner, D.A. Agricultural technologies for climate change in developing countries: Policy options for innovation and technology diffusion. Food Policy 2012, 37, 114-123. [CrossRef]

26. Liu, Z.; Huang, F.; Li, B. Investigating contribution factors to China's grain output increase in period of 2003 to 2011 . Trans. Chin. Soc. Agric. Eng. 2013, 29, 1-8.

27. Vicente-Serrano, S.M.; Cabello, D.; Tomás-Burguera, M.; Martín-Hernández, N.; Beguería, S.; Azorin-Molina, C.; Kenawy, A.E. Drought Variability and Land Degradation in Semiarid Regions: Assessment Using Remote Sensing Data and Drought Indices (1982-2011). Remote Sens. 2015, 7, 4391-4423. [CrossRef]

28. Maqsood, J.; Farooque, A.A.; Wang, X.; Abbas, F.; Acharya, B.; Afzaal, H. Contribution of Climate Extremes to Variation in Potato Tuber Yield in Prince Edward Island. Sustainability 2020, 12, 4937. [CrossRef]

29. Zhao, J.; Li, K.; Wang, R.; Tong, Z.; Zhang, J. Yield Data Provide New Insight into the Dynamic Evaluation of Maize's Climate Suitability: A Case Study in Jilin Province, China. Atmosphere 2019, 10, 305. [CrossRef]

30. Hodrick, R.J.; Prescott, E.C. Postwar US business cycles: An empirical investigation. Money Credit Bank 1997, 29, 1-16. [CrossRef]

31. Ahumada, H.; Garegnani, M.L. Assessing HP filter performance for Argentina and US macro aggregates. J. Appl. Econ. 2000, 3, 257-284. [CrossRef]

32. Ravn, M.O.; Uhlig, H. On adjusting the Hodrick-Prescott filter for the frequency of observations. Rev. Econ. Stat. 2002, 84, 371-376. [CrossRef]

33. $\mathrm{Wu}, \mathrm{L}$; $\mathrm{Zhou,} \mathrm{H.C.} \mathrm{Urban} \mathrm{water} \mathrm{demand} \mathrm{forecasting} \mathrm{based} \mathrm{on} \mathrm{HP} \mathrm{filter} \mathrm{and} \mathrm{fuzzy} \mathrm{neural} \mathrm{network.} \mathrm{J.} \mathrm{Hydroinform.} \mathrm{2010,} \mathrm{12,}$ 172-184.

34. Bunnoon, P.; Chalermyanont, K.; Limsakul, C. Multi-substation control central load area forecasting by using HP-filter and double neural networks (HP-DNNs). Int. J. Electr. Power Energy Syst. 2013, 44, 561-570. [CrossRef]

35. Tang, D.D. Three frequency selective filters and their applications in China. J. Quant. Tech. Econ. 2007, 9, 144-156.

36. Forman, R.T. Land Mosaic: The Ecology of Landscapes and Regions; Cambridge University Press: Cambridge, UK, 1995.

37. Na, R. Spatio-Temproal Variation Characteristics of Desertification in Hulunbeier Sandy Land. Master's Thesis, Inner Mongolia Normal University, Hohhot, China, 2017.

38. Zhao, J.F.; Guo, J.P.; Mu, J. Exploring the relationships between climatic variables and climate-induced yield of spring maize in Northeast China. Agric. Ecosyst. Environ. 2015, 207, 79-90. [CrossRef]

39. Zhao, J.F.; Guo, J.P.; Xu, Y.H.; Mu, J. Effects of climate change on cultivation patterns of spring maize and its climatic suitability in Northeast China. Agric. Ecosyst. Environ. 2015, 202, 178-187. [CrossRef]

40. Qin, S.; Li, L.; Wang, D.; Zhang, J.; Pu, Y. Effects of limited supplemental irrigation with catchment rainfall on rain-fed potato in semi-arid areas on the Western Loess Plateau, China. Am. J. Potato Res. 2012, 90, 33-42. [CrossRef]

41. Ministry of Agriculture and Rural Affairs of the People's Republic of China. Implement the Incentive Policy of Seed Production Counties and Accelerate the Construction of National Potato Breeding Base 2019. Available online: http:/ /www.zzj.moa.gov.cn/ gzdt/201906/t20190610_6316421.htm (accessed on 5 December 2019).

42. Tang, J.; Wang, J.; Fang, Q.; Wang, E.; Yin, H.; Pan, X. Optimizing planting date and supplemental irrigation for potato across the agro-pastoral ecotone in North China. Eur. J. Agron. 2018, 98, 82-94. [CrossRef] 
43. Escuredo, O.; Seijo-Rodríguez, A.; Rodríguez-Flores, M.S.; Meno, L.; Seijo, M.C. Changes in the Morphological Characteristics of Potato Plants Attributed to Seasonal Variability. Agriculture 2020, 10, 95. [CrossRef]

44. Fan, J.; Wu, L.; Zhang, F.; Cai, H.; Zeng, W.; Wang, X.; Zou, H. Empirical and machine learning models for predicting daily global solar radiation from sunshine duration: A review and case study in China. Renew. Sustain. Energy Rev. 2019, 100, 186-212. [CrossRef]

45. Woldeselassie, A.; Dechassa, N.; Alemayehu, Y.; Tana, T.; Bedadi, B. Soil and Water Management Practices as a Strategy to Cope with Climate Change Effects in Smallholder Potato Production in the Eastern Highlands of Ethiopia. Sustainability 2021, 13, 6420. [CrossRef]

46. Zheng, Z.; Zhao, H.; Liu, Z.; He, J.; Liu, W. Research Progress and Development of Mechanized Potato Planters: A Review. Agriculture 2021, 11, 521. [CrossRef]

47. Zhao, F. Solving the Problem of Population Loss in Northeast China; China Population News: Beijing, China, 2018 ; p. 2.

48. Gong, Z.Q.; Zhang, D.Y. Study on the current situation and Countermeasures of population loss in Northeast China. Bus. Econ. 2020, 10-11. [CrossRef]

49. Su, B.D.; Huang, J.L.; Sanjit, K.M.; Zhai, J.Q.; Wang, Y.J.; Wen, S.S.; Gao, M.N.; Lv, Y.R.; Jiang, S.; Jiang, T. Insight from CMIP6 SSP-RCP scenarios for future drought characteristics in China. Atmos. Res. 2021, 250, 105375. [CrossRef] 